\title{
OBSERVATIONS ABOUT LECTURERS' ATTITUDES AND THEIR USE OF EDUCATIONAL SOFTWARE AND DIGITAL RESOURCES
}

\author{
Ramón Garrote Jurado', Tomas Pettersson² \\ ${ }^{1}$ University of Borås (SWEDEN) \\ ${ }^{2}$ Librarian and Science Teacher (SWEDEN)
}

\begin{abstract}
This article presents findings from an action research project. It is based on data from participants in a Learning Management Systems (LMS) course given to educators in Cuba, Guatemala, Peru and Brazil. The data were first collected from the participants during the course, and approximately one year later, the participants were asked to fill out another questionnaire outlining their experiences after the course.

The course used Live USB-Mediated Education (LUME), a method based on a complete package of course material and programs executable from portable memory devices, thus allowing participants to work on any computer on their own time.

The results show that positive attitudes about open educational resources (OER), educational software and collaborative methods go together and are likely to result in a wider use of computerfacilitated methods and free digital material.

The authors assert that the lecturers' pedagogical motivation rather than their technical skill determine whether and to what extent they will use educational software; additionally, the results indicate that to reap the pedagogical benefits of educational software, teachers must understand how information sharing and collaborative methods can improve learning and teaching.
\end{abstract}

Keywords: E-learning; Information Technology; Learning Management Systems; Open Educational Resources; Engineering Education; Developing Countries; Action Research.

\section{BACKGROUND}

Some of the data presented in this article have been published previously [1]-[3]. The course Adaptation engineering education to the use of net-independent software (AENIS, 15 ECTS-point, corresponding to ten weeks of full-time study) was designed and first given in Cuba in March 2010 by the first author of this article. At the same time we started to collect information from the participants in order to improve the course and learn more about issues regarding the use of educational software in higher education, using the action research methodology suggested by Kurt Lewin 1946 [4]. The course was intended to give engineering educators the skills to handle a Learning Management System (LMS) and later act as pioneers and support people for an LMS in their workplaces [2]. Similar projects with the aim of increasing the use of educational software in both elementary and higher education have been conducted in many developing countries [5],[6]. During the course, the participants were introduced in the context of problem-based learning (PBL).

The shortage of computers and internet access in Cuba presented a special challenge. To enable access to the course material (which is available for free online), it was stored on USB drives along with software that was executable directly from the memory stick. That way, the participants could work on any available computer on their own time and save their work between sessions [2]. Only open educational resources (OER) [7] were used, so all of the material could be copied freely. After the course was finished in Cuba, the authors of this article coined the term LUME, an acronym for Live USB Mediated Education [8]. The course was later given in Guatemala, Peru and Brazil (May 2010, November 2010 and December 2012, respectively) with only minor changes in the course material and the same time frame for lectures, workshops and the final project. The main difference was that in Brazil, more time was used to discuss pedagogical methods and the importance of collaborative efforts than in Guatemala and Peru. The decision to put more focus on learning theories was made because early results from Cuba and Guatemala indicated that the participants had no problems handling the software once they understood how information and communication technology (ICT) could benefit teaching and learning [2]. It is a general observation that the easy copying and sharing of information is a key aspect of ICT; therefore, we have to use OER to reap the full benefits of ICT in 
education. A non-commercial LMS is needed to allow free copying and distribution of material, and in the course described in this study, the free, open-source LMS, Moodle, was used.

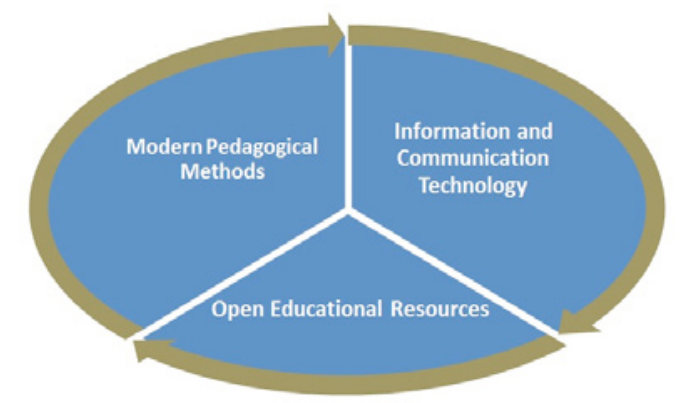

Figure 1. The aim of the AENIS course [9].

At the beginning of the course, the participants gathered for two weeks of lectures, workshops and hands-on training. This was followed by three months of work on their assignments, i.e., to adapt a course to the use of an LMS. Over that period, the participants were strongly encouraged to engage in discussions, work together and share their experiences within the group. The intention was to further promote the transition of the group into a community of learners [10] and elicit long-term collaborative efforts [8]. In Cuba, the university strongly supported the project, and the participants were highly motivated. According to several former participants (personal communication, November 2014), since completing the course, the participants have continued to work together to develop computersupported education in Cuba. In Guatemala and Peru, the institutional support was not as strong as in Cuba or Brazil, and it was more of a personal choice whether the participants completed the course.

\subsection{Educational software}

ICT is widely used in the education system and in industry and government. In this article, we use the term "educational software" to refer to computer programs that are generally intended to facilitate teaching, learning and course administration. Educational software can facilitate a wide range of pedagogical methods. That in itself does not mean that ICT is always beneficial to teaching or learning. Foreseeable learning outcomes and effects on the learner's experience should be taken into consideration when the use of ICT is planned. This process is called constructive alignment [11]. Usually, it is convenient to bring educational software together in a Learning Management System (LMS). An LMS is a "toolbox" of software intended to facilitate learning, teaching and course administration [12]. The features of an LMS can be divided into four groups: Tools for distribution, tools for communication, tools for interaction and tools for course administration [13].

\subsection{Modern pedagogical methods}

Pedagogical development in the last century has demonstrated a shift from teaching-centred to learning-centred pedagogical methods [14]. This change is associated with changes in the view of knowledge and learning. The view that knowledge can be transferred unaltered from books and teachers to students has largely been replaced by the constructivist view that knowledge is created in a process in which the learner is an active participant. When learners form knowledge by processing new information and combining it with previous knowledge, it is usually enhanced by interaction with the outside world and particularly with other people. To highlight this aspect, the term "social constructivism" is often used [15],[16]. We support the view that teaching should facilitate learning by designing and implementing procedures that take the student's previous knowledge and experience into consideration. Learning, or the creation of knowledge, should be facilitated by a combination of theory, experience and practice. The learning experience should be enhanced by interaction and collaborative efforts [17, p 54-56]. In recent decades, we have seen how PBL [18] and active learning [19] combine these ideas.

\subsection{Open educational resources (OER)}

A commonly accepted definition of OER is as follows: "open educational resources are digitized materials offered freely and openly for educators, students and self-learners to use and reuse for teaching, learning and research" [20],[21, p. 30]; therefore, to reap the full benefits of ICT in education, 
we must make use of OER because a key property of ICT is the ease of copying and disseminating digital information [22],[23].

\subsection{Aim and purpose of this article}

The research presented here is action research in line with the principles outlined by Dewey and Lewin: a process of observation - planning - action that can be repeated many times (Lewin, 1946). This article aims to investigate whether the teachers' attitudes toward OER and educational software can be used to predict the extent to which they will apply computer-facilitated collaborative methods. The article highlights key factors in the introduction of educational software and presents a list of recommendations based on the authors' research and experiences. It is primarily aimed at lecturers in higher education and people otherwise engaged in the training of teachers.

\section{METHODOLOGY}

Action research is described by Lewin as "a spiral of steps where each step is composed of a circle of planning, action and fact-finding" [4, p 38]. When this is applied to education, information from one occasion is used to decide about changes in course material and plans for lectures etc. in the future.

\subsection{Data collection}

Questionnaires and group discussions were used to obtain the participants' opinions regarding the course and the use of LMS and OER in education (table 2 below). The opinions regarding the course were provided anonymously via an assessment questionnaire (table 1 below). The course was intended to promote the use of ICT in education; therefore, the participants' assessment was only a first step in the course evaluation. To outline the practical effects of the course, the participants' experiences and attitudes were surveyed approximately one year after the course was finished. It was difficult to get in touch with many of the participants, but approximately two-thirds of the participants answered the questionnaire (below).

\subsection{Data interpretation}

The responses from the four groups are presented and compared to follow up the early course assessment and evaluate the long-term return of the course at the group level. Individual responses were analysed to investigate the factors that affect teachers' decisions regarding whether and how to use ICT or refrain from doing so. All of the responses to statements in the questionnaires were analysed statistically, and the correlations (Pearson's r) were noted [24, p. 630-640].

\subsection{Scope and limitations}

All of the participants were lecturers at Latin American universities, but the results can be applied to a wide range of higher education. In some cases (on which we have commented below), the responses from the Cuban lecturers must be viewed with special regard for the severe shortage of computers and internet access in Cuba. Some of the participants did not pass the course, and some could not be reached for follow-up. No one refused to take part in the survey, so the risk of participant bias is small.

\section{RESULTS}

\subsection{First survey}

Two weeks into the course, the participants anonymously filled out a course assessment with a number of statements and responses given on a five-point Likert scale: 1=l fully agree, 2=l agree, $3=$ Neutral, $4=\mid$ disagree, $5=\mid$ strongly disagree. To compare the groups, we selected three statements (A, B and C, below and table 1). At the same time, the participants responded to statements regarding OER and LMS using a similar scale. To compare the groups, we selected statements 1-6 (below and table 2-3). Table 1 shows the responses to the statements on the students' assessment questionnaire that was filled out anonymously after two weeks of on-campus activity. Because the course evaluation was given anonymously, all of the participants are shown regardless of whether they answered the questionnaire one year later. 
Table 1. Responses to the statements on the students' assessment.

\begin{tabular}{|c|c|c|c|c|c|c|c|}
\hline No & Country & Statement & 1 & 2 & 3 & 4 & 5 \\
\hline \multirow[t]{4}{*}{ A } & Cuba $(\mathrm{N}=15)$ & \multirow[t]{4}{*}{ The course fulfilled my expectations. } & 15 & & & & \\
\hline & Guatemala $(\mathrm{N}=21)$ & & 12 & 9 & & & \\
\hline & Peru(N=11) & & 11 & & & & \\
\hline & $\operatorname{Brazil}(\mathrm{N}=20)$ & & 15 & 5 & & & \\
\hline \multirow[t]{4}{*}{ B } & Cuba $(\mathrm{N}=15)$ & \multirow{4}{*}{$\begin{array}{l}\text { Videos and other materials were well suited to the course } \\
\text { objectives. }\end{array}$} & 15 & & & & \\
\hline & Guatemala $(\mathrm{N}=21)$ & & 16 & 4 & 1 & & \\
\hline & Peru(N=11) & & 11 & & & & \\
\hline & Brazil(N=20) & & 15 & 5 & & & \\
\hline \multirow[t]{4}{*}{$\mathrm{C}$} & Cuba(N=15) & \multirow{4}{*}{$\begin{array}{l}\text { There was a high level of cooperation and interaction } \\
\text { among the participants. }\end{array}$} & 14 & 1 & & & \\
\hline & Guatemala $(\mathrm{N}=21)$ & & 6 & 14 & 1 & & \\
\hline & Peru(N=11) & & 9 & 2 & & & \\
\hline & $\operatorname{Brazil}(\mathrm{N}=20)$ & & 15 & 5 & & & \\
\hline
\end{tabular}

Comment: All four groups appeared satisfied with the course after two weeks, but the Guatemalan group was less satisfied with the level of cooperation. Table 2 shows the responses to the statements regarding OER. Only the responses of the participants who also answered the questionnaire distributed one year later are shown.

Table 2. Responses to the statements regarding OER after two weeks of on-campus study.

\begin{tabular}{|c|c|c|c|c|c|c|c|}
\hline No. & Country & Statement & 1 & 2 & 3 & 4 & 5 \\
\hline \multirow[t]{4}{*}{1} & Cuba(n=10) & \multirow{4}{*}{$\begin{array}{l}\text { I believe the use of the free course material on the } \\
\text { internet (OER) offers great opportunities for } \\
\text { increasing the quality of higher education. }\end{array}$} & 9 & 1 & & & \\
\hline & Guatemala(n=13) & & 8 & 3 & 1 & & \\
\hline & $\operatorname{Peru}(n=6)$ & & 5 & & 1 & & \\
\hline & Brazil(N=13) & & 12 & 1 & & & \\
\hline \multirow[t]{4}{*}{2} & Cuba(n=10) & \multirow{4}{*}{$\begin{array}{l}\text { I am willing to make much of my course material } \\
\text { available as freeware on the internet. }\end{array}$} & 9 & 1 & & & \\
\hline & Guatemala(n=13) & & 8 & 4 & 1 & & \\
\hline & Peru $(n=6)$ & & 5 & 1 & & & \\
\hline & Brazil(N=13) & & 8 & 2 & 3 & & \\
\hline \multirow[t]{4}{*}{3} & Cuba $(\mathrm{N}=10)$ & \multirow{4}{*}{$\begin{array}{l}\text { I would like to cooperate with other lecturers to } \\
\text { develop freely available course material. }\end{array}$} & 9 & 1 & & & \\
\hline & Guatemala(N=13) & & 9 & 3 & 1 & & \\
\hline & $\operatorname{Peru}(\mathrm{N}=6)$ & & 5 & 1 & & & \\
\hline & Brazil(N=13) & & 12 & 1 & & & \\
\hline \multirow[t]{4}{*}{4} & Cuba(N=10) & \multirow{4}{*}{$\begin{array}{l}\text { I think peer recognition is important as a reward for } \\
\text { work on freeware. }\end{array}$} & 10 & & & & \\
\hline & Guatemala $(\mathrm{N}=13)$ & & 4 & 9 & & & \\
\hline & $\operatorname{Peru}(\mathrm{N}=6)$ & & 5 & 1 & & & \\
\hline & Brazil( $(\mathrm{N}=13)$ & & 13 & & & & \\
\hline
\end{tabular}

Table 3 shows the responses to the statements regarding LMS after two weeks of on-campus activity.

Table 3. Responses to the statements regarding LMS after two weeks of on-campus study.

\begin{tabular}{|c|c|c|c|c|c|c|c|}
\hline No. & Country & Statement & 1 & 2 & 3 & 4 & 5 \\
\hline \multirow[t]{4}{*}{5} & Cuba(n=10) & \multirow{4}{*}{$\begin{array}{l}\text { An LMS can facilitate the work of the lecturers to a large } \\
\text { extent. }\end{array}$} & 8 & 2 & & & \\
\hline & Guatemala(n=13) & & 8 & 5 & & & \\
\hline & Peru $(n=6)$ & & 4 & 2 & & & \\
\hline & Brazil(N=13) & & 12 & 1 & & & \\
\hline \multirow[t]{4}{*}{6} & Cuba $(n=10)$ & \multirow{4}{*}{$\begin{array}{l}\text { An LMS can increase the performance of the students at } \\
\text { my institution. }\end{array}$} & 9 & 1 & & & \\
\hline & Guatemala(n=13) & & 10 & 3 & & & \\
\hline & Peru $(n=6)$ & & 4 & 2 & & & \\
\hline & Brazil(N=13) & & 12 & 1 & & & \\
\hline
\end{tabular}




\subsection{Summary of the course assessment and the participants' attitudes after two weeks of study}

Tables 1-3 show only small differences in attitudes between the groups after two weeks of on-campus activity. The course apparently met the participants' expectations, and the anonymous course assessment confirmed the first author's impression that the course filled a need for most of the participants. In all of the groups, most of the participants agreed that OER offers good opportunities for improving the quality of higher education and were willing to disseminate their own material online as OER. They also agreed that an LMS can facilitate the work for both teachers and students.

\subsection{Observations}

A few observations are worth mentioning as viable explanations for the differences in outcome. In both Cuba and Brazil, the participants were given sufficient time to complete the course, resulting in almost $100 \%$ attendance during the first two weeks. Additionally, the course received a great deal of attention from the institutions, including senior staff members participating in the course. In Brazil, the participants spontaneously formed small groups to work on specific issues and compare notes. From personal communication, we have concluded that there was a major difference in the way the work continued after the initial two weeks. In Cuba and Brazil, the groups continued to work closely together, and after completing the course, they continued their cooperation.

\subsection{Second survey}

Approximately one year after the course was finished, the participants were asked to fill out a questionnaire containing 15 statements. The responses to statements 7-18 were given on a on a three-point scale, as follows: $A=$ On many occasions, $B=$ Test or one-time basis and $C=$ Not at all.

Table 4. Responses to statements regarding the use of ICT by former course participants.

\begin{tabular}{|c|c|c|c|c|c|}
\hline No. & Country & Statement & A & $\mathrm{B}$ & $\mathrm{C}$ \\
\hline \multirow[t]{4}{*}{7} & Cuba $(n=10)$ & \multirow{4}{*}{$\begin{array}{l}\text { During the last year, the computer network was used in my } \\
\text { courses to enable the students to discuss issues and tasks in the } \\
\text { course. }\end{array}$} & 9 & 1 & \\
\hline & Guatemala $(n=13)$ & & 9 & 4 & \\
\hline & Peru $(n=6)$ & & 3 & 3 & \\
\hline & Brazil $(\mathrm{N}=13)$ & & 10 & 3 & \\
\hline \multirow[t]{4}{*}{8} & Cuba $(n=10)$ & \multirow{4}{*}{$\begin{array}{l}\text { During the last year, the computer network was used in my } \\
\text { courses to enable the students to cooperate on assignments in } \\
\text { the course. }\end{array}$} & 9 & 1 & \\
\hline & Guatemala $(n=13)$ & & 9 & 3 & 1 \\
\hline & Peru $(n=6)$ & & 3 & 3 & \\
\hline & Brazil $(\mathrm{N}=13)$ & & 11 & 2 & \\
\hline \multirow[t]{4}{*}{9} & Cuba $(n=10)$ & \multirow{4}{*}{$\begin{array}{l}\text { During the last year, the computer network was used in my } \\
\text { courses to facilitate more general discussions. }\end{array}$} & 10 & & \\
\hline & Guatemala $(n=13)$ & & 5 & 7 & 1 \\
\hline & Peru $(n=6)$ & & 3 & 2 & 1 \\
\hline & Brazil $(\mathrm{N}=13)$ & & 12 & 1 & \\
\hline
\end{tabular}

By comparing the responses from the four groups of participants, we can draw some preliminary conclusions. From the statements regarding the utilization of the university's computer network (7-9 above), it is obvious that the Cuban lecturers have been the most active, while the Peruvian group is lagging behind. 
Table 5. Responses to statements regarding the use of LUME.

\begin{tabular}{|c|c|c|c|c|c|}
\hline No. & Country & Statement & A & B & C \\
\hline \multirow[t]{4}{*}{10} & Cuba $(n=10)$ & \multirow[t]{4}{*}{ I have used LUME in courses since completing the course. } & 8 & 2 & \\
\hline & Guatemala $(n=13)$ & & 7 & 4 & 2 \\
\hline & Peru $(n=6)$ & & 3 & 3 & \\
\hline & Brazil $(\mathrm{N}=13)$ & & 9 & 3 & 1 \\
\hline \multirow[t]{4}{*}{11} & Cuba $(n=10)$ & \multirow[t]{4}{*}{ I am planning to use LUME in the next few years. } & 9 & 1 & \\
\hline & Guatemala $(n=13)$ & & 11 & 2 & \\
\hline & Peru $(n=6)$ & & 5 & 1 & \\
\hline & Brazil $(N=13)$ & & 12 & 1 & \\
\hline
\end{tabular}

The responses to statements 10 and 11 show that most of the participants have used the LUME method since they completed the course. All of them intended to do so in the next few years, which is a sign that the LUME method fills a need for the lecturers.

Table 6. Responses to statements 12-15.

\begin{tabular}{|c|c|c|c|c|c|}
\hline No. & Country & Statement & $A$ & $\mathrm{~B}$ & $\mathrm{C}$ \\
\hline \multirow[t]{4}{*}{12} & Cuba $(\mathrm{N}=10)$ & \multirow{4}{*}{$\begin{array}{l}\text { During the last year, I have searched the internet for } \\
\text { OER in the form of text and images. }\end{array}$} & 9 & 1 & \\
\hline & Guatemala $(\mathrm{N}=13)$ & & 10 & 2 & 1 \\
\hline & Peru $(\mathrm{N}=6)$ & & 6 & & \\
\hline & Brazil $(\mathrm{N}=13)$ & & 13 & & \\
\hline \multirow[t]{4}{*}{13} & Cuba $(\mathrm{N}=10)$ & \multirow{4}{*}{$\begin{array}{l}\text { During the last year, I have searched the internet for } \\
\text { OER in the form of videos. }\end{array}$} & 4 & 4 & 2 \\
\hline & Guatemala $(\mathrm{N}=13)$ & & 5 & 6 & 2 \\
\hline & Peru $(\mathrm{N}=6)$ & & 2 & 4 & \\
\hline & Brazil $(\mathrm{N}=13)$ & & 11 & 2 & \\
\hline \multirow[t]{4}{*}{14} & Cuba $(N=10)$ & \multirow{4}{*}{$\begin{array}{l}\text { During the last year, I have made educational text or } \\
\text { images available on the internet as OER. }\end{array}$} & 7 & 2 & 1 \\
\hline & Guatemala $(\mathrm{N}=13)$ & & 8 & 4 & 1 \\
\hline & Peru $(\mathrm{N}=6)$ & & 4 & 1 & 1 \\
\hline & Brazil $(\mathrm{N}=13)$ & & 10 & 2 & 1 \\
\hline \multirow[t]{4}{*}{15} & Cuba $(\mathrm{N}=10)$ & \multirow{4}{*}{$\begin{array}{l}\text { During the last year, I have made educational video } \\
\text { available on the internet as OER. }\end{array}$} & 7 & 2 & 1 \\
\hline & Guatemala $(\mathrm{N}=13)$ & & 5 & 5 & 3 \\
\hline & Peru $(\mathrm{N}=6)$ & & 3 & 3 & \\
\hline & Brazil $(N=13)$ & & 10 & 2 & 1 \\
\hline
\end{tabular}

Statements 12-15 outline the extent to which the lecturers have searched the internet for free material and made material available as OER. Here, access to internet is critical, and even when the internet is available, as in Guatemala and Peru, it may still be too expensive to allow the type of internet surfing we are accustomed to in developed countries. The responses show that the Cubans, who are very positive regarding the use of OER (see table 2), have not browsed the internet for suitable material very much because of the shortage of computers and internet access in Cuba. 
Table 7. Responses to statements 16-18.

\begin{tabular}{|c|c|c|c|c|c|}
\hline No. & Country & Statement & A & $\mathrm{B}$ & C \\
\hline \multirow[t]{4}{*}{16} & Cuba $(N=10)$ & \multirow{4}{*}{$\begin{array}{l}\text { During the last year, the students in my classes made } \\
\text { use of OER in the form of text and images. }\end{array}$} & 9 & 1 & \\
\hline & Guatemala $(\mathrm{N}=13)$ & & 10 & 3 & \\
\hline & Peru $(\mathrm{N}=6)$ & & 5 & 1 & \\
\hline & Brazil $(\mathrm{N}=13)$ & & 12 & 1 & \\
\hline \multirow[t]{4}{*}{17} & Cuba $(\mathrm{N}=10)$ & \multirow{4}{*}{$\begin{array}{l}\text { During the last year, the students in my classes made } \\
\text { use of OER in the form of videos. }\end{array}$} & 9 & 1 & \\
\hline & Guatemala $(\mathrm{N}=13)$ & & 4 & 6 & 3 \\
\hline & Peru $(\mathrm{N}=6)$ & & 1 & 5 & \\
\hline & Brazil $(N=13)$ & & 11 & 2 & \\
\hline \multirow[t]{4}{*}{18} & Cuba $(\mathrm{N}=10)$ & \multirow{4}{*}{$\begin{array}{l}\text { During the last year, the students in my classes made } \\
\text { use of OER in the form of software. }\end{array}$} & 8 & 2 & \\
\hline & Guatemala $(\mathrm{N}=13)$ & & 3 & 8 & 2 \\
\hline & Peru $(\mathrm{N}=6)$ & & & 6 & \\
\hline & Brazil (N=13) & & 12 & 1 & \\
\hline
\end{tabular}

The responses to statements 16,17 and 18 show that most of the Cuban and Brazilian respondents have found relevant free material to use in their courses, despite the problems with internet access in Cuba. We conclude that the teachers in Peru and Guatemala are more reluctant to use OER, in particular videos and software. This difference points to the importance of the teachers' acceptance of OER and willingness to adapt their teaching to new technology.

Table 8. Responses to statements 19-23.

\begin{tabular}{|c|c|c|c|c|c|c|c|}
\hline No & Country & Statement & 1 & 2 & 3 & 4 & 5 \\
\hline \multirow[t]{4}{*}{19} & Cuba $(n=10)$ & \multirow{4}{*}{$\begin{array}{l}\text { Limited access to computers and the internet are the } \\
\text { major obstacles to utilizing the LUME method. }\end{array}$} & 8 & 2 & & & \\
\hline & Guatemala $(n=13)$ & & 5 & 1 & 2 & 2 & 3 \\
\hline & Peru $(n=6)$ & & & 2 & & 3 & 1 \\
\hline & Brazil $(\mathrm{N}=13)$ & & & & 2 & 4 & 7 \\
\hline \multirow[t]{4}{*}{20} & Cuba $(n=10)$ & \multirow{4}{*}{$\begin{array}{l}\text { Established, traditional teaching practices are the } \\
\text { major obstacle to utilizing the LUME method. }\end{array}$} & 7 & 2 & 1 & & \\
\hline & Guatemala $(n=13)$ & & 3 & 8 & & 2 & \\
\hline & Peru $(n=6)$ & & 3 & 3 & & & \\
\hline & Brazil $(\mathrm{N}=13)$ & & 10 & 3 & & & \\
\hline \multirow[t]{4}{*}{21} & Cuba $(n=10)$ & \multirow{4}{*}{$\begin{array}{l}\text { Teachers' lack of time and education are major } \\
\text { obstacles to utilizing the LUME method. }\end{array}$} & 8 & 2 & & & \\
\hline & Guatemala $(n=13)$ & & 4 & 6 & 1 & 2 & \\
\hline & Peru $(n=6)$ & & & 3 & 2 & 1 & \\
\hline & Brazil $(\mathrm{N}=13)$ & & 9 & 4 & & & \\
\hline \multirow[t]{4}{*}{22} & Cuba $(n=10)$ & \multirow{4}{*}{$\begin{array}{l}\text { I think the LUME method can be an effective tool in } \\
\text { higher education. }\end{array}$} & 10 & & & & \\
\hline & Guatemala $(n=13)$ & & 10 & 2 & 1 & & \\
\hline & Peru $(n=6)$ & & 2 & 3 & 1 & & \\
\hline & Brazil $(N=13)$ & & 13 & & & & \\
\hline \multirow[t]{4}{*}{23} & Cuba $(n=10)$ & \multirow{4}{*}{$\begin{array}{l}\text { I think the LUME method can be an effective tool for } \\
\text { self-studies and distance education. }\end{array}$} & 10 & & & & \\
\hline & Guatemala $(n=13)$ & & 10 & 2 & 1 & & \\
\hline & Peru $(n=6)$ & & 5 & 1 & & & \\
\hline & Brazil $(\mathrm{N}=13)$ & & 12 & 1 & & & \\
\hline
\end{tabular}

Most of the participants from Cuba and Brazil perceived traditions in teaching and education as the major obstacle to using the LUME method. The participants from Guatemala and Peru were less aware of traditions as an obstacle, but at the same time, they appeared to be more reluctant to make changes in their teaching. 


\subsection{Observations on the group level}

A year after finishing the course, most of the participants had used a computer network to facilitate collaboration and interaction, and most of them planned to use the LUME method in the future. The long-term result of the AENIS course looks better in Cuba and Brazil than in the other two countries; in Cuba and Brazil, a larger proportion of the students were utilizing ICT, and a larger proportion of the lecturers had used and planned to use the LUME method. The final five statements (19-23) outline the respondents' perceptions of the LUME method and some barriers to its utilization. The responses show some differences among the four countries. In Cuba, there is a severe shortage of computers and internet access, but the lecturers appeared willing to experiment with both technical and pedagogical innovations. In Brazil, the situation is similar to that of universities in the western world, with low-cost internet available to both teachers and students. The participants from Guatemala and Peru were less aware of traditions as an obstacle for development, but they were also less prone to use OER, at least videos and software. The use of a computer network to facilitate collaborative efforts (statements 7,8 and 9) showed the same trend; the Guatemalan and Peruvian lecturers appeared to favour more traditional methods than their Cuban and Brazilian colleagues.

\subsection{Analysis of the individual participants' responses}

To obtain a deeper and more comprehensive understanding of the possible obstacles to a wider, pedagogically sound utilization of ICT, we checked the correlations among questions 1-23 (the course assessment was filled out anonymously). The Pearson r-value was calculated for each group separately and for all of the groups put together (see below). For some statements in some groups, there is no r-value (the sign \#DIV/0) because all of the participants ticked the same box, and there can be no linear regression in such cases.

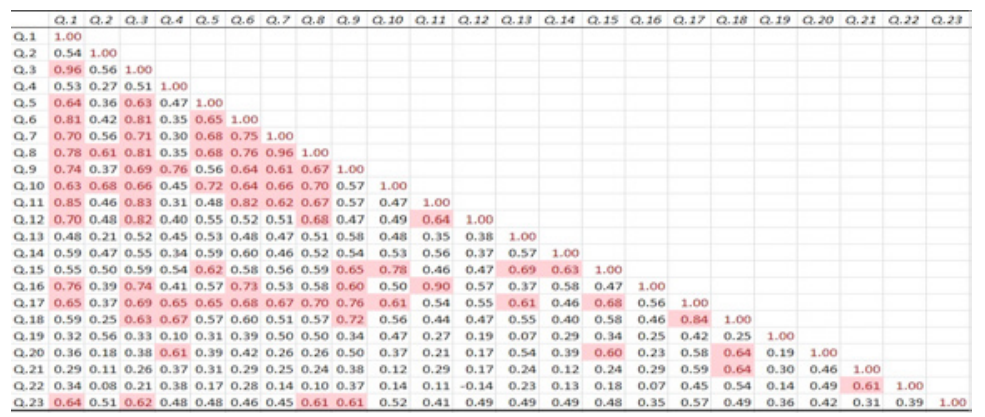

Figure 2. Correlations for all participants (Cuba, Guatemala, Peru, Brazil).

The responses to statements 1-4 regarding the participants' attitudes about OER were strongly correlated with the responses to statements 1 and 3, indicating that teachers who believe that "...the use of the free course material on the internet (OER) offers great opportunities for increasing the quality of higher education" are also interested in engaging in collaborative efforts to produce OER. Attitudes about LMS were strongly correlated with attitudes about OER, such that we can conclude that the participants expect to find an LMS particularly useful when it is combined with OER. This is what we expected because the use of proprietary software or commercial courseware in an LMS makes it difficult to engage in collaborative efforts without violating the copyright. The responses to statements 7-23 were given approximately one year after completing the course. The first group of statements (7-9) outlines the use of computer networks. Not surprisingly, these statements were correlated with each other; one would expect students to use a discussion forum or similar features for different purposes once it is up and working. One can clearly see correlations between this group and statements $1,3,5,6,10,11$ and 17 . That is to say that students are more likely to engage in online collaborative efforts and interactions if the teacher has a positive attitude towards OER (statements 1 and 3), uses LMS (statements 5 and 6 ) and is open to the use of media files as course material (statement 17). As the LUME method was designed to facilitate the use of free information by copying and sharing material, it is no surprise that statements 10 and 11 follow the same pattern.

\begin{tabular}{lllllllllllllllllllllllllll} 
& 0.1 & 0.2 & 0.3 & 0.4 & $Q .5$ & 0.6 & 0.7 & 0.8 & 0.9 & 0.10 & 0.11 & 0.12 & 0.13 & 0.14 & 0.15 & 0.16 & 0.17 & 0.18 & 0.19 & 0.20 & 0.21 & 0.22 & 0.23 \\
\hline 0.12 & 0.67 & 0.44 & 0.80 & 0.45 & 0.52 & 0.43 & 0.45 & 0.65 & 0.53 & 0.47 & 0.57 & 1.00 & 0.49 & 0.39 & 0.51 & 0.49 & 0.53 & 0.45 & 0.20 & 0.14 & 0.12 & -0.16 & 0.53
\end{tabular} \begin{tabular}{ll|l|l|l|l|l|l|l|l|l|l|l|l|l|l|l|l|l|l|l|l|l|l|l}
\hline & 0.13 \\
\hline & 0.64 & 0.33 & 0.69 & 0.66 & 0.71 & 0.65 & 0.66 & 0.71 & 0.84 & 0.66 & 0.46 & 0.49 & 1.00 & 0.58 & 0.80 & 0.49 & 0.90 & 0.80 & 0.28 & 0.59 & 0.39 & 0.35 & 0.66 \\
\hline
\end{tabular}

Figure 3. Correlations when the Cuban group is excluded (participants; Guatemala, Peru, \& Brazil). 
Statements 12 and 13 outline the extent to which the lecturers have searched for OER online. One would expect that most teachers with an interest in utilizing OER (as indicated by statements $1,3,10$ and 11) would spend time browsing the internet, and apparently they do, except in Cuba (see the correlations for statement 13 when the Cubans are eliminated). This result is to be expected if we remember that access to computers and the internet is limited in Cuba, which makes it impossible for many teachers to search the internet at random or download large files, regardless of their interest in doing so. The Cuban students were able to use media files by copying them from USB sticks and the intranet at the universities. Statements 14 and 15 correlated well with statements 16 to 18 , indicating that teachers who make material available as OER also tend to utilize OER in their courses. Those correlations were weaker in Cuba, and the only viable explanation is that shortages of computers and internet access prevent both teachers and students who would otherwise be interested from engaging in the OER movement. The teachers' thoughts about the LUME method, as shown in statements 1923 , showed rather weak correlations with the rest of the questionnaire. The responses to statement 19 reflect the different situations in the four countries; therefore, we cannot expect any particular pattern to emerge when we compare that statement with the others. The responses to statements 20 and 21 indicate what the teachers perceive as alternative obstacles for a wider use of the LUME method. The Brazilian participants considered old-fashioned teachers and teaching methods to be barriers for the implementation of LUME, but the participants from Guatemala and Peru did not share their opinion. This is somewhat surprising as the observation from statements 2 and 4 (see table 2) indicated a more reluctant attitude towards collaborative and student-centred methods from the Guatemalan and Peruvian groups. Although we believe that the latter groups have far more traditional views of teaching and learning than the Cuban and Brazilian groups, they are either not aware of these views or do not see them as a problem.

\section{SUMMARY OF THE RESULTS}

There are many similarities between the Cuban and the Brazilian groups, the first and latest group to participate in the course. In those groups, we see more positive attitudes toward the use of digital material and educational software than in the Guatemalan and Peruvian group. The willingness to work with colleagues and share material show the same pattern, in which the Cuban and Brazilian groups appear to have more positive attitudes. The correlations among responses to the statements suggest that all of the lecturers are distributed along a scale of attitude ranging from the highly motivated and eager to learn and utilize ICT to the more reluctant albeit still positive participants. The lecturers from Guatemala and Peru were less aware of traditions as an obstacle to development than their Cuban and Brazilian colleagues, but they were also less likely to use OER, at least videos and software. The same trend could be observed in the use of a computer network to facilitate collaborative efforts: The Guatemalan and Peruvian lecturers appeared to favour more traditional methods. We conclude that awareness of traditions is important to overcoming the barriers to educational innovation. We found a clear trend in the material that is consistent with our experiences and observations and with information from informal contacts with several of the participants after they took part in the investigations. Positive attitudes from lecturers regarding OER, educational software and computer-facilitated collaborative methods all go together and are likely to result in a wider application of computer-facilitated methods and digital material.

\section{DISCUSSION}

Many researchers assert that technology, support and training are necessary but not sufficient to guarantee the optimal utilization of ICT in education [25]. The findings reported in this article confirm the claim that wider utilization of computer-enhanced education demands an initial effort from teachers and institutions [26]. In this two-step investigation, we were able to see differences that were not obvious in the first survey after we gathered additional information approximately one year later. The methods we used to learn from experience and improve the course are consistent with the action research principles outlined by Dewey and Lewin, a process of observation - planning - action that can be repeated many times [4]. ICT is a powerful tool that can facilitate a wide range of pedagogical methods, but to reap the full benefits of it in higher education, lecturers must combine the technology with appropriate ideas of teaching and learning. The way ICT is applied should take into consideration the course aims, the students' prior experience, etc., and this will only happen if the lecturers are motivated and prepared to develop their competence and adapt their teaching practice to the available educational software [27]. 
In constructivist theories of teaching and learning, students' interactions are important [28]. Constructivist methods are based on the idea that individuals develop their own knowledge from information, experience and interaction with other people or the outside world. From this perspective, memorizing facts is only a small step in the creation of knowledge; it is through using and processing memorized information that a person translates it into functional knowledge. Based on theories that acknowledge the importance of the learner as an active participant in the pedagogical process [14],[16],[29], we assert that the use of ICT in education can only be expected to have significant impact when it is used to facilitate learner-centred, collaborative methods. Therefore, teachers need to understand the underlying pedagogical ideas to reap the full benefits of ICT in education. The impact of ICT on the lecturers' work situation can be divided into two categories: change in workload and change in outcome, i.e., students' performance. It may take some initial effort to implement a new method or tool, and the term "perceived ease of use" [30] describes how hard it is to get started [31]. Considering how user-friendly a great deal of educational software is, the demand on the lecturers' computer literacy in most cases is no higher than we would expect for an average student in a developed country. Consequently, if lecturers find ICT difficult to handle, or not useful in their courses, the problem is likely to be a lack of understanding of its pedagogical possibilities.

The attitudes and reactions of colleagues, or peer recognition, are very important to most people. Unfortunately, teachers at many educational institutions do not interact and learn together; hence, they do not form a community of practice [32]. Instead, they work independently within a set frame of traditions that defines both their course content and pedagogical methods. This can only satisfy the needs of students as long as education is dominated by persistent, predefined knowledge.

\section{CONCLUSIONS AND RECOMMENDATIONS}

Our results and experiences confirm that peer recognition and the satisfaction of personal development are important motivators for educators. A long-term, pedagogically sound utilization of ICT is most likely to occur if lecturers form a community of practice with a generous exchange of information and collaborative efforts. The formation of a community of practice that results in the free sharing of information and a supportive workplace atmosphere is more likely to occur if lecturers are given time to discuss key ideas in modern pedagogy, such as communities of practice and social constructivism (as a theory of learning). It is important for teachers to experience collaborative learning first-hand if they are to pass it on to their students. Understanding how the course aims relate to underlying theories of learning and teaching makes it easier to reap the benefits of an LMS. During staff development, peer recognition and group identity are important and can be enhanced by attention from senior staff and common activities outside of lecture time.

\section{REFERENCES}

[1] Garrote Jurado, R. and T. Pettersson, ATTITUDES AND UTILIZATION OF OPEN EDUCATIONAL RESOURCES, in 8TH INTERNATIONAL CONFERENCE OF EDUCATION, RESEARCH AND INNOVATION, ICERI2015, Editor. 2015, Proceedings: Seville, Spain. p. 6317-6323.

[2] Garrote Jurado, R., T. Pettersson, and M. Christie, LiveUSB Mediated Education: A method to facilitate computer supported education. Australasian Journal of Educational Technology, 2011. 27(4): p. 610-632.

[3] Garrote Jurado, R., T. Pettersson, and A. Regueiro Gomez. EDUCATIONAL SOFTWARE AND PEDAGOGICAL DEVELOPMENT- SUCCESS FACTORS IN TEACHERS TRAINING. in 18th Scientific Convention on Enginnering ans Architecture CUJAE2016. 2016. Havana, Cuba: Proceedings.

[4] Lewin, K., Action research and minority problems. Journal of Social Issues, 1946. 2(4): p. 3446.

[5] Mtebe, J.S., Learning Management System success: Increasing Learning Management system usage in higher education in sub-Saharan Africa. International Journal of Education and Development using Information and Communication Technology, 2015. 11(2): p. 51.

[6] Stasinakis, P. and M. Kalogiannakis, Using Moodle in Secondary Education: A Case Study of the Course" Research Project" in Greece. International Journal of Education and Development using Information and Communication Technology, 2015. 11(3): p. 50-64. 
[7] D'Antoni, S., Open Educational Resources: reviewing initiatives and issues. Open Learning: The Journal of Open and Distance Learning, 2009. 24(1): p. 3-10.

[8] Garrote Jurado, R. and T. Pettersson, LiveUSB Mediated Education (LUME). International Journal of Education and Development using Information and Communication Technology, 2011. 7(1): p. 141-144.

[9] Garrote Jurado, R. and T. Pettersson. LiveUSB Mediated Education (LUME). in Congreso Iberoamericano Educación y Sociedad (CIEDUC 2011). 2011. La Serena, Chile.

[10] Wilson, D.M., Work in progress - Engaging engineering students in broader abet outcomes via community of learners instruction, in Frontiers In Education Conference - Global Engineering: Knowledge Without Borders, Opportunities Without Passports, 2007. FIE '07. 37th Annual. 2007. p. S1A-7-S1A-8.

[11] Biggs, J., Teaching for quality learning at university. 1999, Buckingham: Open University Press.

[12] Kats, Y., Learning Management Systems and Instructional Design: Best Practices in Online Education. 2013: IGI Global. 1-467.

[13] Garrote Jurado, R. and T. Pettersson, The use of learning management systems: $A$ Longitudinal Case Study. eleed, 2011. 8(1).

[14] Bruner, J., Actual Minds, Possible Worlds. 1986, Cambridge, MA: Harvard University Press.

[15] Powell, K.C. and C.J. Kalina, Cognitive and social constructivism: Developing tools for an effective classroom. Education, 2009. 130(2): p. 241-251.

[16] Vygotsky, L.S., Mind in society: The development of higher psychological proceses. 1978 , Cambridge, MA: Harvard University Press.

[17] Garrote Jurado, R., Educational Software in Engineering Education, in Department of Education. 2015, Stockholm University: Stockholm.

[18] Barrows, H.S. and R.M. Tamblyn, Problem-based learning : an approach to medical education. Springer series on medical education ; v. 1. 1980, New York: Springer Pub. Co. xvii, 206 p.

[19] Meyers, C. and T.B. Jones, Promoting Active Learning. Strategies for the College Classroom. 1993: ERIC.

[20] D'Antoni, S., Open educational resources: The way forward - Deliberations of an international community of interest. Paris: UNESCO Institute for Educational Planning (IIEP), 2008.

[21] OECD, Giving Knowledge for free - the emergence of open educational resources. 2007.

[22] Atkins, D.E., J.S. Brown, and A.L. Hammond, A Review of the OEal resources (OER) movement: Achievements, challenges, and new opportunities, Report to The William and Flora Hewlett Foundation, 2007.

[23] Gourley, B. and A. Lane, Re-invigorating openness at The Open University: The role of open educational resources. Open Learning, 2009. 24(1): p. 57-65.

[24] Cohen, L., L. Manion, and K. Morrison, Research Methods in Education, 7th Edition. 2011, New York: Routledge.

[25] Blin, F. and M. Munro, Why hasn't technology disrupted academics' teaching practices? Understanding resistance to change through the lens of activity theory. Comput. Educ., 2008. 50(2): p. 475-490.

[26] Butakov, S., O. Solodky, and B. Swar, LMS Implementation in Startup Institutions: Case Study of Three Projects. Learning Management Systems and Instructional Design: Best Practices in Online Education, 2013: p. 40-54.

[27] Kihoza, P., et al., Classroom ICT integration in Tanzania: Opportunities and challenges from the perspectives of TPACK and SAMR models. International Journal of Education and Development using Information and Communication Technology, 2016. 12(1): p. 107.

[28] Duffy, T.M. and D.H. Jonassen, Constructivism: New Implications for Instructional Technology, in Constructivism and the Technology of Instruction: A Conversation, T.M. Duffy and D.H. Jonassen, Editors. 1992, Lawrence Erlbaum Associates, Inc.: Hillsdale, NJ. p. 1-16. 
[29] Bruner, J., Acts of meaning. 1990, Cambridge, MA: Harvard University Press.

[30] Al-Senaidi, S., L. Lin, and J. Poirot, Barriers to adopting technology for teaching and learning in Oman. Computers \&amp; Education, 2009. 53(3): p. 575-590.

[31] Garrote Jurado, R., Barriers to a wider Implementation of LMS in Higher Education: a Swedish case study, 2006-2011. eleed, 2012. 9.

[32] Wenger, E., Communities of practice: A brief introduction. 2011. 